\title{
RESEARCH OF IDENTITY FUNCTIONS IN STUDENTS
}

УДК 159.9316 .6

DOI https://doi.org/10.32843/2663-

5208.2020 .15 .40

\section{Джаббарова л.В.}

викладач кафедри педагогіки,

психології, початкової освіти

та освітнього менеджменту

КЗ «Харківська гуманітарно-педагогічна

академія» Харківської обласної ради у статті розглядається проблема ідентичності та ї̈ фуннкиій. Відмічається важливість проблеми збереження чілісності й стабільності «Я» в сучасному транссрормаційному суспільстві. Проведено огляд сучасних наукових вітчизняних $i$ зарубіжних поглядів на ідентичність $і$ їі фрункції. Розглянуто фуннкії ідентичності, що запропоновані G. Adams ma S. Marshall. Наголошено на тому, що в сучасній психологічній науці немає загального погляду на види ідентичності та їх співвідношення. Розглянуто ідентичність із двох основних ракурсів: соціальної ідентичності, яка виражається в усвідомленні й переживанні своєі належності до соціальних груп, спільнот, особистісної ідентичності, яка включає в себе набір рис, інших індивідуальних характеристик, які відрізняються постійністю, дають змогу диференціювати індивіда від інших людей, здатністю підтримувати, продовжувати історію власного Я, що зберігає свою чілісність, незважаючи на зміну окремих його компонентів.

Вибірка дослідження - 250 студентів віком від 19 до 23 років. Описана шкала вивчення фуннкцій ідентичності, розроблена Serafini, Maitland, \& Adams, яка спрямована на вивчення структурно-срункціональних особливостей ідентичності студентів та оцінювання фрункцій ідентичності, а саме: структурної, гармонійної, цільової, орієнтованої, самоконтролюючої фоункцій. Проаналізовані результати дослідження: установлено, що серед фрункцій ідентичності студентів найбільш сформованою $є$ самоконтролююча, що свідчить про досить високий локус контролю та сумлінність студентів. Дещо менш вираженою $\epsilon$ цільова фрункція, яка забезпечує цілеспрямованість і самомотивованість студентів. Ще менш вираженою $є$ орієнтовна фрункція ідентичності, що забезпечує надання здатності розпізнавати потенціал у вигляді майбутніх можливостей та альтернативних виборів особистості. Найменш розвиненою $є$ структурна ффункція ідентичності, що свідчить про недостатню визначеність і впорядкованість власного «Я» студентів, усвідомлення себе як незалежної та унікальної особистості.
Ключові слова: ідентичність, фуункції ідентичності, особистісна ідентичність, соціальна ідентичність, структурна, гармонійна, цільова, орієнтовна, самоконтролююча, студенти.

The article considers the problem of identity and its functions. The importance of the problem of preserving the integrity and stability of the "l" in a modern transformational society is noted. A review of modern scientific domestic and foreign views on identity and its functions. Identity functions proposed by G. Adams and S. Marshall are considered. It is emphasized that in modern psychological science there is no general view of the types of identity and their relationship. Identity from two main angles is considered: social identity, which is expressed in the awareness and experience of belonging to social groups, communities, personal identity, which includes a set of traits, other individual characteristics that are consistent, allow to differentiate the individual from other people, ability to maintain, to continue the history of one's own Self, which preserves its integrity, despite the change of its individual components.

Sample: 250 students aged 19 to 23 years. A scale for studying identity functions was developed by Serafini, Maitland, \& Adams, which aims to study the structural and functional features of student identity and evaluate identity functions, namely: structural, harmonious, target, oriented, self-controlling functions. As a result of the analysis of the conducted research it was established that among the functions of students' identity the most formed is self-controlling, which indicates a fairly high locus of control and honesty of students.

The target function, which provides purposefulness and self-motivation of students, is somewhat less pronounced. Even less pronounced is the indicative identity function, which provides the ability to recognize potential in the form of future opportunities and alternative personality choices. The least developed is the structural function of identity, which indicates a lack of certainty and orderliness of students' own "I", self-awareness as an independent and unique individual.

Key words: identity, identity functions, personal identity, social identity, structural, harmonious, target, approximate, self-controlling, students.
Постановка проблеми. Стрімкі трансформації характеризують сучасне суспільство. Людям усе складніше вдається підтримувати внутрішню стабільність і відповідність «Я». Сучасний світ характеризується втратою стійких меж, цінностей, завдяки яким особистість визначає своє місце в навколишньому світі, який стрімко змінюється. Усі ці аспекти підсилюють проблему особистісного вибору, міру особистісної відповідальності. Водночас відбуваються процеси усвідомлення людиною себе «тут і зараз», відкриття нових меж бачення себе та навколишнього світу в інформаційному світі, який постійно ускладнюеться.

Аналіз останніх досліджень і публікацій. Багато сучасних дослідників, серед яких - Г. Андрєєва, Е. Бєлінська, Н. Іванова, Н. Лебєдєва, М. Козлов, В. Павленко й інші, звертають увагу на те, що відбувається втрата меж і цінностей, які були стійкими, завдяки яким особистість визначає себе, своє місце в соціумі, тобто відбувається так звана криза ідентичності. Як наслідок, виникає нестабільність культури. Узв'язкузцим, зазначаєЮ. Рєз- 
нік та М. Тлостанова, проблема ідентичності $€$ складною та багатомежною для сучасної людини. Ї̈̈ осмислення дає змогу «більш детальне та глибоке розуміння суб'єктності індивіда як у контексті культури та суспільства, так і в складних умовах постсучасності» [3].

Ще Е. Еріксон наголошував на тому, що почуття ідентичності може усвідомлюватися лише в ситуації кризи, коли виникають різноманітні труднощі в самовизначенні, коли ідентичність має протиріччя в результаті зіткнення позитивної та негативної ідентичності, а також у ситуації позитивного переживання власної ідентичності. В інших випадках автор наголошує на неусвідомленості ідентичності [4, с. 20].

Постановка завдання. Головною метою статті $є$ емпіричне дослідження функцій ідентичності в студентської молоді.

Виклад основного матеріалу дослідження. Поняття ідентичності пов'язують з ім'ям Е. Еріксона, так як його погляд на розуміння ідентичності $\epsilon$ базовою позицією та відправною крапкою для всіх наступних дослідників ідентичності. Ідентичність у розумінні Е. Еріксона є «суб'єктивним почуттям і якістю особистісної самототожності й безперервності, яку можна спостерігати, яке поєднане з певною вірою в тотожність і безперервність деякої картини світу, яка розділяється з іншими людьми» [10]. Ідентичність визначається автором як важлива характеристика цілісності, самостійності та зрілості особистості. Ідентичність - це тотожність самому собі. Мати ідентичність означає мати власний образ себе, який приймається особистістю, у всьому різноманітті відносин особистості до навколишнього світу, почуття адекватності і стабільності володіння особистості власним Я незалежно від внутрішніх і зовнішніх змін, здатність особистості до повноцінного вирішення завдань, які виникають перед нею на кожному етапі її розвитку. Відповідно до Е. Еріксона, поняття ідентичності присутнє на всьому життєвому циклу людини - вісім основних взаємопов'язаних стадій розвитку, кожна з яких може бути вирішена для подальшого процесу розвитку без перешкод. За Е. Еріксоном, бути ідентичним - означає переживати хронологію власного життя як єдине ціле [5].

Хоча багато дослідників звертають увагу на те, що основу еріксонівського розуміння ідентичності заклав У. Джеймс. У текстах автор використовував цей термін, але називав його характером.

М. Заковоротна вважає, що становлення ідентичності відбувається в процесі тяжкого вибору між легко набутим Я - скопійованим, запозиченим, і Я, яке створюється власними зусиллями і стараннями [2, с. 12].

У сучасній психологічній науці немає загального погляду на види ідентичності та їх співвід- ношення. Ми погоджуємося з ідеями науковців І. Губеладзе, Н. Іванова, Д. Леонтьєв, Н. Паттуріна, Г. Теджфел, Дж. Тернер, які, незважаючи на представлену кількість різноманітних видів ідентичності особистості, усе більше акцентують увагу на особистісній і соціальній ідентичності, які, маючи спільні основи функціонування, різняться сутнісною природою.

Виявлені суперечності щодо питання співвідношення цих двох ідентичностей: одні вчені вважають їх взаємодоповнюючими елементами одного цілого (Е. Еріксон, Д. Леонтьєв, Ю. Хабермас), другі підкреслюють первинність соціальної ідентичності (Дж. Брейкуел, І. Губеладзе, Р. Дженкінс), треті визначають у них два полярні конструкти (Г. Теджфел, Дж. Тернер). Ми розглядаємо ідентичність із двох основних ракурсів: соціальної ідентичності, яка виражається в усвідомленні та переживанні своєї належності до соціальних груп, спільнот, особистісної ідентичності, яка включає в себе набір рис, інших індивідуальних характеристик, що відрізняються постійністю, дають змогу диференціювати індивіда від інших людей, здатністю підтримувати, продовжувати історію власного Я, що зберігає свою цілісність, незважаючи на зміну окремих його компонентів.

Adams and Marshall, у свою чергу, припускали, що ідентичність як соціально-психологічна структура має певні властивості. Це "саморегулювальна система", яка функціонує як така, що спрямовує увагу як певний фільтр обробки інформації; система, що керує враженнями й обирає стратегію поведінки. Крім того, як соціально-психологічну конструкція ідентичність має власне функціональне призначення. Adams and Marshall запропонували п'ять функцій ідентичності [1; 7, с. 1-14].

Структурна функція ідентичності. Вона забезпечує визначеність, упорядкованість власного «Я», усвідомлення себе як незалежної та унікальної особистості. Ця функція відповідає за зниження тривожності й переживань щодо себе. Розвиток цієї функції сприяє підвищенню почуття власної гідності й самоприйняття особистості.

Гармонійна функція ідентичності забезпечує послідовність, узгодженість і гармонію між цінностями, переконаннями й обов'язками особистості. Ця функція відповідає за використання особистістю більш здорових та адаптивних механізмів захисту для забезпечення узгодженості між цінностями, переконаннями й обов'язками особистості. Розвиток цієї функції сприяє вирішенню внутрішніх конфліктів, гармонійності й удосконаленню особистості.

Цільова функція ідентичності. Забезпечує цілепокладання та побудову певної моделі поведінки особистості. Ця функція відповідає за цілеспрямованість і самомотивованість людини Blustein \& Palladino, а також за зміст 
і напрям обов'язків, цінностей і цілей. Розвиток цієї функції сприяє кращому усвідомленню цілей, виробленню певної стратегії поведінки, що сприятиме активному їх досягненню.

Орієнтовна функція ідентичності забезпечує надання здатності розпізнавати потенціал у вигляді майбутніх можливостей та альтернативних виборів особистості. Ця функція відповідає за майбутню орієнтацію, де мета зумовлюється контекстом досягнення усвідомлення себе можливого. Розвиток цієї функції сприяє вихованню конгруентності між усвідомленням себе теперішнього і майбутнього.

Самоконтролююча функція ідентичності забезпечує зміст самоконтролю та вольової регуляції особистості. Ця функція відповідає за певний локус контролю людини та її сумлінність. Розвиток цієї функції сприяє зменшенню зовнішнього локусу контролю, що сприяе збільшенню впевненості в самоконтролі власного життя, а також підвищенню сумлінності, що сприяє організованому та планомірному вирішенню завдань [1; 8, с. 361-389].

За своєю сутністю самі функції можуть розглядатися як частина того, що Еріксон називав «оптимальне почуття ідентичності» [1; 4, с. 83].

Оптимальне почуття ідентичності переживається як приємне й легке відчуття психосоціального благополуччя. Його найбільш очевидним вираженням $є$ відчуття себе «у своїй тарілці» й внутрішня впевненість у визнанні з боку авторитетів.

Serafini, Maitlend \& Adams у 2006 році вдосконалили The Functions of Identity Scale, яка вивчає сформоване й синтезоване відчуття власної особистості. Основна увага приділяється внутрішній роботі ідентичності: які функції ідентичності працюють, а не як вона сформована. Теоретично функції структури ідентичності намагаються описати, як саме ідентичність забезпечує індивідів почуттям структури, з яким вони розумітимуть саморелевантну інформацію, відчуття гармонії між обраними якостями, віруваннями й обов'язками, майбутню орієнтацію, де мета зумовлюється контекстом досягнення усвідомлення себе можливого та виховання себе теперішнього і майбутнього, орієнтування на активне досягнення цілей, які співвідносяться з установленим почуттям власного самоконтролю, вольової регуляції в процесі встановлення та досягнення цілей, рухаючись до майбутніх планів та аналізуючи здобутий досвід у самоактуальний спосіб [1; 8, с. 378].

Остання версія The Functions of Identity Scale розроблена Serafini, Maitland \& Adams складається 3 п'яти субшкал, кожна вимірює одну з п'яти запропонованих функцій ідентичності. Респонденти відмічають, який пункт відповіді найкраще їх характеризує: 1 - ніколи; 2 - рідко; 3 - іноді; 4 - часто; 5 - завжди. Відповіді підсу- мовуються для кожної субшкали функції, формуючи 5 сум функцій для кожного індивіда. Ця шкала складається з п'яти факторів: структури, гармонії, цілей, майбутнього та самоконтролю. Кожна вимірюється тричі. 5-факторна модель порівнюється з моделлю, що складається з одного фактора функції загальної ідентичності й включає в себе 15 кінцевих пунктів. Результати показали, що 5-факторна модель статистично сильніше підтримує теоретичне поняття 5 функцій ідентичності [1; 8, с. 382].

Звертаючи увагу на результати дослідження Adams \& Marshall, необхідно зазначити, що додатково визначено відноснезначення кожної функції ідентичності для індивідів. Відповідно, перша функція - структурна, проявляється більш високою самооцінкою, самоприйняттям, позитивним самосприйняттям власного тіла. Друга функція - гармонійна, проявляється в соціальній та академічній успішності. Третя функція - цільова, проявляється в самостійності й цілепокладанні. Четверта функція - самоконтролююча, проявляється вільною волею та протистоянням зовнішнім впливам. І п'ята функція - майбутнє, проявляється більшою успішністю, більш чіткими й усвідомленими кар'єрними цілями, прагненнями та майбутнім визначенням [1; 7, с. 14].

Емпіричне дослідження проводилося протягом 2015-2017 рр. на базі Національного технічного університету «Харківський політехнічний інститут» і на базі комунального закладу «Харківська гуманітарно-педагогічна академія» Харківської обласної ради. На різних етапах дослідження взяли участь 250 студентів віком від 19 до 23 років, з них 118 - жіночої статі $(47,2 \%), 132$ - чоловічої статі $(52,8 \%)$.

Аналіз рівня сформованості функцій ідентичності студентів здійснювався за опитувальником вивчення функцій ідентичності The Functions of Identity Scale, розробленим Serafini, Maitland \& Adams, який спрямований на вивчення структурно-функціональних особливостей ідентичності студентів та оцінювання функцій ідентичності, а саме: структурної, гармонійної, цільової, орієнтованої, самоконтролюючої функцій.

За допомогою методики В. Семиченко маємо можливість запропонувати рівні кожної функції ідентичності:

- високий рівень характеризує студентів, у яких функція сформована достатньо. Кількісні показники коливаються від 11 до 15 балів;

- середній рівень визначає студентів, у яких функція сформована на недостатньому рівні. Кількісні показники за опитувальником оцінюються від 6 до 10 балів;

- низький рівень притаманний студентам, у яких функція практично не сформована. Кількісні показники за методикою оцінюються від 1 до 5 балів. 
Рівень сформованості функцій ідентичності студентів

\begin{tabular}{|l|c|c|c|}
\hline \multirow{2}{*}{ Функцї̈ ідентичності студентів } & \multicolumn{3}{|c|}{ Рівень сформованості (кількість досліджуваних, у \%) } \\
\cline { 2 - 4 } & Високий & Середній & Низький \\
\hline Структурна & 53,6 & 46,4 & 0 \\
\hline Гармонійна & 78,4 & 21,6 & 0 \\
\hline Цільова & 73,2 & 26,8 & 0 \\
\hline Орієнтовна & 56,8 & 41,6 & 1,6 \\
\hline Самоконтролююча & 82,0 & 18,0 & 0 \\
\hline
\end{tabular}

Результати емпіричного дослідження функцій ідентичності студентської молоді представлені в таблиці 1.

Аналізуючи представлені в таблиці дані, можна зробити такі висновки: найбільш сформованою функцією ідентичності в студентів є самоконтролююча, що свідчить про досить високий локус контролю та сумлінність студентів. Тобто більшість студентів схильні відчувати впевненість у самоконтролі власного життя, що сприяє організованому й планомірному вирішенню завдань. Дещо менш вираженою є цільова функція, яка забезпечує цілеспрямованість і самомотивованість студентів. Ще менш вираженою $є$ орієнтовна функція ідентичності, що забезпечує надання здатності розпізнавати потенціал у вигляді майбутніх можливостей та альтернативних виборів особистості. Найменш сформованою є структурна функція, яка забезпечує визначеність і впорядкованість власного «я», усвідомлення себе як незалежної та унікальної особистості. Також варто зазначити, що 1,6\% студентів мають низький рівень сформованості орієнтовної функції ідентичності. За іншими функціями ідентичностістудентів із низьким рівнем немає.

Результати аналізу показали (див. таблицю 1), що рівень сформованості структурної функції ідентичності студентів виражений так: дещо більше ніж половина респондентів належить до високого рівня $(53,6 \%)$, тобто більше ніж половина студентів відчуває почуття власної гідності та приймає себе, а інші 46,4\%, які мають середній рівень, можуть іноді відчувати певну тривожність і переживання щодо себе. Низький рівень відсутній. У таблиці 1 показано, що рівень сформованості гармонійної функції ідентичності студентів представлений так: більшість респондентів за цією функцією ідентичності належить до групи 3 високим рівнем сформованості $(78,4 \%)$, тобто майже $80 \%$ студентів відчувають послідовність, узгодженість і гармонію між власними цінностями та переконаннями. До середнього рівня сформованості належать 21,6\% досліджуваних, які можуть мати певні внутрішньоособистісні конфлікти щодо власних цінностей і переконань. I жоден із респондентів не належить до низького рівня сформованості гармо- нійної функції ідентичності. Результати аналізу сформованості цільової функції ідентичності показали, що найбільша кількість респондентів належить до високого рівня сформованості $(73,2 \%)$. Цей відсоток студентів достатньо усвідомлює власні цілі, виробляє певну стратегію поведінки, що сприяє активному їх досягненню. Середній рівень сформованості цієї функції ідентичності мають 26,8\% досліджуваних. У групу з низьким рівнем сформованості не потрапило жодного з респондентів. Рівень сформованості орієнтовної функції ідентичності виражений так: низький рівень сформованості охоплює 1,6\% вибірки, середній рівень сформованості цієї функції ідентичності мають $41,6 \%$ респондентів, які неповною мірою здатні розпізнавати потенціал у вигляді майбутніх можливостей. До високого рівня сформованості належать $56,8 \%$ досліджуваних. Дещо більше ніж половина студентів відчуває конгруентність між усвідомленням себе теперішнього та майбутнього. У таблиці 1 показано, що рівень сформованості самоконтролюючої функції ідентичності студентів представлений так: більшість респондентів за цією функцією ідентичності належить до групи з високим рівнем сформованості (82\%), тобто більшість студентів упевнені в самоконтролі власного життя. До середнього рівня сформованості належать $18 \%$ досліджуваних. I жоден із респондентів не належить до низького рівня сформованості самоконтролюючої функції ідентичності. Отже, серед основних функцій ідентичності студентів превалює самоконтролююча функція ідентичності, що передбачає високий рівень локусу контролю особистості, її вольової регуляції, які сприяють організованому та планомірному вирішенню поставлених перед студентами завдань.

Висновки 3 проведеного дослідження. Отже, особистісна ідентичність включає в себе набір рис та інших індивідуальних характеристик, які відрізняються постійністю й дають змогу зберігати цілісність власного Я, незважаючи на зміну окремих його компонентів у часі та різних сферах діяльності.

Соціальна ідентичність характеризується як переживання й усвідомлення своєї належності до соціальних груп, спільнот. 
Ідентичність - це система, що керує враженнями й обирає стратегію поведінки. Крім того, як соціально-психологічна конструкція ідентичність має своє власне функціональне призначення.

Серед функцій ідентичності студентів найбільш сформованою $є$ самоконтролююча, що свідчить про досить високий локус контролю та сумлінність студентів.

Найменш розвиненою є структурна функція ідентичності, що свідчить про недостатню визначеність і впорядкованість власного «Я» студентів, усвідомлення себе як незалежної та унікальної особистості.

Проведене дослідження не вичерпує всіх аспектів досліджуваної проблеми. Подальше іï вивчення може здійснюватися в напрямі поглибленого вивчення особливостей функцій ідентичності на різних етапах онтогенезу, формування функцій ідентичності особистості з урахуванням впливу різноманітних чинників тощо.

\section{ЛІТЕРАТУРА:}

1. Джаббарова Л.В. Функції ідентичності та засіб їх вивчення. Інноваційні наукові дослідження в сфрері соціології, психології та політичних наук : матеріали Міжнародної науково-практичної конферен- ціï (Sladkovicovo, 10-11marec 2017). Sladkovicovo, Slovak Republik, 2017. C. 61-64.

2. Заковоротная М. В. Идентичность человека. Социально-фрилософрские аспекты : авторефр. дисс. ... докт. фрілософр. наук. Ростов-на-Дону, 1999.

3. Резник Ю.М., Тлостанова М.В. Заключение. Современный человек в поисках идентичности: утрата и обретение идентичности. С. 414.

4. Эриксон Э. Идентичность: юность и кризис. Москва : Флинта, 2006. 342с.

5. Эриксон Э. Детство и общество. Санкт-Петербург, 1996.

6. Adams, G.R. Psychosocial Resources in FirstYear University Students: The Role of Identity Processes and Social Relationships Journal of Youth and Adolescence. 2006. Vol. 35. № 1. P. 81-91.

7. Adams G.R., Marshall S. Developmental social psychology of identity: understanding the person in context. Journal of adolescence. 1996. № 19. C. 1-14.

8. Serafini T.E., Adams G.R. Functions of identity: scale construction and validation. Identity: an international journal of theory and research. 2006. № 2 (4). C. 361-389.

9. Cote J.E. Age-Related Differences in Identity Style. A Cross-Sectional Analysis Current Psychology. 2008. № 27. P. 205-215.

10. Erikson E. Psychosocial Identity In.: A Way of Looking at Things. Selected Papers Ed. By S. Schlein. N.Y., 1995. 